\title{
ANALISIS SENTIMEN PADA TWITTER MENGENAI PASCA BENCANA MENGGUNAKAN METODE NAÏVE BAYES DENGAN FITUR $N$-GRAM
}

\author{
Imam Fahrur Rozi, S.T., M.T ${ }^{1}$, Annisa Taufika Firdausi, S.T., M.T ${ }^{2}$, Khalimatul Islamiyah ${ }^{3}$ \\ 1,2,3Program Studi Teknik Informatika, Jurusan Teknologi Informasi, Politeknik Negeri Malang \\ 1 imam.rozi@polinema.ac.id, ${ }^{2}$ annisa.taufika@polinema.ac.id, ${ }^{3}$ khalimatulislamiyah39@gmail.com
}

\begin{abstract}
Abstrak
Bencana alam sering terjadi di wilayah Indonesia, pemberian bantuan yang efisien dan sesuai kebutuhan sangat berpengaruh terhadap proses pemulihan pasca bencana alam. Melalui twitter masyarakat banyak memberikan respon mengenai bencana alam, akan tetapi respon tersebut belum terklasifikasikan. Oleh karenanya, diperlukan klasifikasi respon masyarakat mengenai bencana alam. Dalam penilitian ini, dilakukan analisis sentimen terhadap tweet dengan mengklasifikasikan kedalam kategori positif atau negatif menggunakan algoritma Nä̈ve Bayes Classifier. Dari hasil klasifikasi tersebut kita dapat memprioritaskan bantuan dengan mengkategorikan setiap hasil klasifikasi. Dari hasil klasifikasi tersebut positif diartikan bantuan berdasarkan kategori tersebut telah terpenuhi sedangkan negatif berarti bantuan tersebut kurang atau dibutuhkan. Penelitian ini juga akan menggunakan fitur $\mathrm{N}$-Gram yaitu unigram dan bigram. Pada pengujian penelitian ini dilakukan empat kali pengujian. Setiap pengujian, presentase data training nya berbeda karena jumlah data training juga berpengaruh terhadap peningkatan nilai akurasi. Hasil dari pengujian tersebut diperoleh nilai akurasi untuk unigram sebesar 76.67\%, 84.44\%, 90.00\% dan 93.33\%. Nilai akurasi untuk bigram sebesar $64.17 \%, 68.89 \%, 75.00 \%, 86.67 \%$. Dari empat pengujian didapatkan hasil akurasi tertinggi pada unigram yaitu sebesar $93.33 \%$ dan bigram sebesar $86.67 \%$. Jadi untuk nilai akurasi unigram lebih tinggi daripada bigram.
\end{abstract}

Kata kunci : Pasca Bencana, Naïve Bayes Classifier, N-Gram

\section{Pendahuluan}

Di Indonesia akhir-akhir ini sering terjadi bencana alam. Selain wilayahnya yang dilintasi jajaran pegunungan berapi dan terletak diantara 2 samudera besar dunia menjadikan wilayah Indonesia rawan tsunami dan gempa bumi. Seperti yang terjadi pada 28 September 2018, gempa berkekuatan 7,5 SR menghantam pulau Sulawesi. Gempa tersebut menghancurkan sejumlah besar bengunan di daerah tersebut serta memicu tsunami yang menghancurkan sebagian besar kota pesisir Palu [1].

Setiap kelompok masyarakat mempunyai pengetahuan dan cara untuk menghadapi bencana demi kelangsungan hidupnya. Diantaranya yaitu dengan penggunaan media sosial yang saat ini semakin banyak digunakan oleh masyarakat termasuk mengenai bencana alam yang terjadi di Indonesia.

Direktur Pelayanan Informasi Internasional Ditjen Informasi dan Komunikasi Publik (IKP), Selamatta Sembiring mengatakan, twitter merupakan salah satu situs jejaring sosial yang paling banyak diakses di Indonesia dan menempati peringkat 5 pengguna twitter terbesar di dunia. Pengguna twitter, berdasarkan data PT Bakrie Telecom, memiliki 19,5 juta pengguna di Indonesia dari total 500 juta pengguna global. Melalui twitter pengguna dapat melakukan tweet dengan topik yang beragam seputar opini mereka atau tentang hal-hal darurat yang terjadi seperti bencana alam.

Tweet dari pengguna tentang bencana alam dapat menjadi informasi untuk menentukan bantuan yang sesuai dengan kebutuhan dan mempercepat pemulihan pasca bencana. Meskipun pemerintah dan organisasi tanggap bencana telah bekerja sama, sentimen dari orang-orang yang terkena dampak bencana sangat menentukan keberhasilan tanggap bencana dan proses pemulihan. Dalam penelitian ini, dilakukan analisis sentimen untuk membantu dan memahami kebutuhan yang tepat setelah bencana sehingga informasi yang dihasilkan dapat membantu banyak pihak untuk mendukung suatu keputusan atau pilihan seperti dengan mengkategorikan berbagai kebutuhan masyarakat seperti tempat tinggal, medis, makanan, air dan listrik. Salah satu teknik pembelajaran untuk analisis sentimen adalah Nä̈ve Bayes Classifier. Metode Nä̈ve Bayes Classifier dianggap sebagai metode yang berpotensi baik untuk melakukan klasifikasi data daripada metode klasifikasi lainnya dalam hal akurasi dan komputasi [2].

Penelitian terkait dengan jurnal yang berjudul Perbandingan Klasifikasi Tugas Akhir Mahasiswa Jurusan Teknik Informatika Menggunakan Metode Nä̈ve Bayes Classifier Dan K-Nearest Neighbor 
mendapatkan hasil bahwa metode Nä̈ve Bayes Classifier menghasilkan nilai akurasi lebih baik, yaitu sebesar $87 \%$ dibandingkan dengan pengujian pada metode K-Nearest Neighbor yang menghasilkan nilai akurasi 84\% [3]. Berdasarkan penjelasan tersebut, penelitian tentang analisis sentimen pada Twitter untuk tanggap bencana dan pemulihan ini menggunakan algoritma Nä̈ve Bayes Classifier untuk mengklasifkasi tweet positif dan negatif dengan menerapkan penggunaan fitur $\mathrm{N}$ gram. Sebagaimana pada penelitian sebelumnya tentang penggunaan n-gram pada analisa sentimen pemilihan kepala daerah jakarta menggunakan algoritma naïve bayes, hasil dari rata-rata nilai accuracy paling besar terdapat pada penggunaan bigram yaitu 0,823 , ini menunjukkan bahwa dengan menggunakan bigram ketepatan akurasi dari sistem lebih baik dibandingkan menggunakan unigram atau trigram, nilai precision tertinggi juga terdapat pada penggunaan bigram dengan 0,76 [4]. Oleh karena itu, penelitian ini akan melakukan Analisis Sentimen Pada Twitter Mengenai Pasca Bencana Menggunakan Metode Nä̈ve Bayes Dengan Fitur $N$ Gram.

\section{Tinjauan Pustaka}

\subsection{Text Mining}

Penambangan teks (bahasa Inggris: text mining) adalah proses ekstraksi pola berupa informasi dan pengetahuan yang berguna dari sejumlah besar sumber data teks, seperti dokumen Word, PDF, kutipan teks, dll. Jenis masukan untuk penambangan teks ini disebut data tak terstruktur dan merupakan pembeda utama dengan penambangan data yang menggunakan data terstruktur atau basis data sebagai masukan. Penambangan teks dapat dianggap sebagai proses dua tahap yang diawali dengan penerapan struktur terhadap sumber data teks dan dilanjutkan dengan ekstraksi informasi dan pengetahuan yang relevandari data teks terstruktur ini dengan menggunakan teknik dan alat yang sama dengan penambangan data. Proses yang umum dilakukan oleh penambangan teks di antaranya adalah perangkuman otomatis, kategorisasi dokumen, penggugusan teks, dan lain-lain [5].

\subsection{Sentiment Analysis}

Sentiment analysis atau analisis sentimen dalam Bahasa Indonesia adalah sebuah teknik atau cara yang digunakan untuk mengidentifikasi bagaimana sebuah sentimen diekspresikan menggunakan teks dan bagaimana sentimen tersebut bisa dikategorikan sebagai sentimen positif maupun sentimen negatif [6]. Pendapat yang hampir sama juga mengatakan di mana analisis sentimen digunakan untuk memahami komentar yang diciptakan oleh pengguna (internet) dan menjelaskan bagaimana sebuah produk maupun brand diterima oleh mereka [7]. Sedangkan pada jurnal yang berjudul Combining Classification and Clustering for Tweet
Sentiment Analysis, analisis sentimen adalah proses yang digunakan untuk menentukan opini, emosi dan sikap yang dicerminkan melalui teks, dan biasanya diklasifikasikan menjadi opini negatif dan positif [8]. Dari ketiga pendapat diatas, bisa diambil kesimpulan bahwa analisis sentimen adalah sebuah proses untuk menentukan sentimen atau opini dari seseorang yang diwujudkan dalam bentuk teks dan bisa dikategorikan sebagai sentimen posisif atau negatif. Sebagaimana yang sudah dituliskan sebelumnya bahwa pengguna internet banyak menuliskan pengalaman, opini dan segala hal yangmenjadi perhatian mereka. Tulisan tentang apa yang mereka rasakan ini berupa perasaan positif, netral maupun negatif yang bisa diungkapkan dengan cara yang cukup kompleks [9].

\subsection{Algoritma Naive Bayes Classifier}

Metode NBC menempuh dua tahap dalam proses klasifikasi teks, yaitu tahap pelatihan dan tahap klasifikasi. Pada tahap pelatihan dilakukan proses analisis terhadap sampel dokumen berupa pemilihan vocabulary, yaitu kata yang mungkin muncul dalam koleksi dokumen sampel yang sedapat mungkin dapat menjadi representasi dokumen. Selanjutnya adalah penentuan probabilitas prior bagi tiap kategori berdasarkan sampel dokumen. Pada tahap klasifikasi ditentukan nilai kategori dari suatu dokumen berdasarkan term yang muncul dalam dokumen yang diklasifikasi. Lebih konkritnya jika diasumsikan dimiliki koleksi dokumen $\mathrm{D}=\left\{\mathrm{d}_{\mathrm{i}} \mid\right.$ $\mathrm{i}=1,2, \ldots|\mathrm{D}|\}=\left\{\mathrm{d}_{1}, \mathrm{~d}_{2}, \ldots, \mathrm{d}_{|\mathrm{D}|}\right\}$ dan koleksi kategori $\mathrm{V}$ $=\left\{\mathrm{v}_{\mathrm{j}} \mathrm{j}=1,2, \ldots|\mathrm{V}|\right\}=\left\{\mathrm{v}_{1}, \mathrm{v}_{2}, \ldots, \mathrm{v}_{\mid \mathrm{V}} \mid\right\}$. Klasifikasi NBC dilakukan dengan cara mencari probabilitas $\mathrm{P}\left(\mathrm{V}=\mathrm{v}_{\mathrm{j}} \mid\right.$ $\mathrm{D}=\mathrm{d}_{\mathrm{i}}$ ), yaitu probabilitas category vj jika diketahui dokumen di. Dokumen di dipandang sebagai tuple dari kata-kata dalam dokumen, yaitu $\left\langle a_{1}, a_{2}, \ldots, a_{n}\right\rangle$, yang frekuensi kemunculannya diasumsikan sebagai variable random dengan distribusi probabilitas Bernoulli (McCallum and Nigam, 1998). Selanjutnya klasifikasi dokumen adalah mencari nilai maksimum dari :

$$
\mathrm{V}_{\mathrm{MAP}}=\underset{v j \in V}{\operatorname{argmax}} P\left(v_{j} \mid\left(a_{1}, a_{2}, \ldots, a_{n}\right)\right.
$$

Teorema Bayes menyatakan tentang probabilitas bersyarat menyatakan:

$$
\mathrm{P}(\mathrm{B} \mid \mathrm{A})=\frac{\mathrm{P}(\mathrm{A} \mid \mathrm{B}) \mathrm{P}(\mathrm{B})}{\mathrm{P}(\mathrm{A})}
$$

Dengan menerapkan teorema Bayes persamaan (1) dapat ditulis:

$$
\mathrm{V}_{\mathrm{MAP}}=\underset{v j \in V}{\operatorname{argmax}} \frac{P\left(a_{1}, a_{2}, \ldots, a_{n} \mid v_{j}\right) P\left(v_{j}\right)}{P\left(a_{1}, a_{2}, \ldots, a_{n}\right)}(3)
$$

Karena nilai $P(a 1, a 2, \ldots$, an) untuk semua vj besarnya sama maka nilainya dapat diabaikan, sehingga persamaan (3) menjadi : 


$$
\mathrm{V}_{\mathrm{MAP}}=\underset{v j \in V}{\operatorname{argmax}} P\left(a_{1}, a_{2}, \ldots, a_{n} \mid v_{j}\right) P\left(v_{j}\right)
$$

Dengan mengasumsikan bahwa setiap kata dalam $\left\langle a_{1}, a_{2}, \ldots, a_{n}\right\rangle$ adalah independent, maka $P\left(a_{1}, a_{2}, \ldots, a_{n}\right)$ dalam persamaan (4) dapat ditulis sebagai :

$$
P\left(a_{1}, a_{2}, \ldots, a_{n} \mid v_{j}\right)=\prod_{i} P\left(a_{i} \mid v_{j}\right)
$$

Sehingga persamaan (4) dapat ditulis :

$$
\mathrm{V}_{\mathrm{MAP}}=\underset{v j \in V}{\arg \max } P\left(v_{j}\right) \prod_{i} P\left(a_{i} \mid v_{j}\right)
$$

Nilai $\mathrm{P}(\mathrm{vj})$ ditentukan pada saat pelatihan, yang nilainya didekati dengan :

$$
P\left(v_{j}\right)=\frac{\left|d o c_{j}\right|}{\mid \text { Contoh } \mid}
$$

Dimana $\mid$ doc $\mathrm{j} \mid$ adalah banyaknya dokumen yang memiliki kategori $\mathrm{j}$ dalam pelatihan, sedangkan |Contoh| banyaknya dokumen dalam contoh yang digunakan untuk pelatihan.

Untuk nilai $\mathrm{P}(\mathrm{wk} \mid \mathrm{vj})$, yaitu probabilitas kata wk dalam kategori $\mathrm{j}$ ditentukan dengan:

$$
P\left(w_{k} \mid v_{j}\right)=\frac{n_{k}+1}{n+\mid \text { vocabulary } \mid}
$$

Dimana nk adalah frekuensi munculnya kata wk dalam dokumen yang ber kategori vj, sedangkan nilai $\mathrm{n}$ adalah banyaknya seluruh kata dalam dokumen berkategori vj, dan |vocabulary| adalah banyaknya kata dalam contoh pelatihan [10].

Pengujian pada performa algoritma Naïve Bayes Classifier dilakukan dengan menguji tingkat akurasi, presisi dan recall.

Dalam melakukan penghitungan tingkat akurasi algoritma Nä̈ve Bayes Classifier dengan rumus sebagai berikut:

$$
\text { Akurasi }=\frac{\sum \text { data benar }}{n \text { dokumen }} \times 100 \%
$$

Rumus untuk melakukan penghitungan tingkat presisi sebagai berikut:

Presisi $=\frac{\sum \text { data positif atau negatif }}{n \text { dokumen positif atau negatif }} \times 100 \%(10)$

Rumus untuk melakukan penghitungan recall sebagai berikut:

$$
\text { recall }=\frac{\sum \text { doc relevan dan terambil }}{\sum \text { seluruh dokumen relevan }} \times 100 \%
$$

Proses perhitungan prioritas bantuan dilakukan untuk menyamakan data dan melihat data mana yang lebih tinggi dalam suatu dataset sehingga dapat ditampilkan prioritas dari bantuan yang dibutuhkan. Perhitungan prioritas bantuan perkategori dilakukan dengan rumus sebagai berikut:

$$
\text { Jumlah }=\frac{\sum \text { seluruh dataset }}{\sum \text { dataset perkategori }}
$$

Rumus untuk menghitung rata-rata dari dataset perkategori :
JumlahKategori $=\frac{\sum \text { dataset perkategori }}{\sum \text { dataset positif atau negatif }}$

Selanjutnya menghitung keseluruhan dari hasil rata-rata perhitungan dengan rumus:

Hasil $=$ Jumlah $x$ JumlahKategori

\subsection{Fitur N-Gram}

Bahasa tidak terbentuk dari kata-kata individu, tetapi terdiri dari urutan kata individu dan frase 2, 3 atau lebih kata yang lebih dikenal $n$-gram dengan masing-masing kata tersebut mengandung informasi tersendiri, contoh penerapan n-gram khususnya trigram pada kalimat "The cat sat on the mat" menjadi "the cat sat", "cat sat on", "sat on the" dan "on the mat" apabila terdapat sebuah punctuation seperti koma, semi kolon, dan sebagainya maka pada proses $n$-gram tidak melewatinya melainkan membuat $n$-gram baru dengan kata setelah karakter tersebut misalnya pada kalimat "Three blind mice, see how they run" untuk trigram menjadi "three blind mice", "see how they" dan "how they run" [11]

Pada penelitian ini menerapkan $n$-gram dengan pemecahan kata pada kalimat ulasan meliputi unigram adalah pemecahan kata pada kalimat ulasan dengan $n=1$ atau term tunggal dan bigram adalah pemecahan $n$-kata pada kalimat ulasan dengan $\mathrm{n}=2$. Berikut ilustrasi penerapan $n$-gram pada kalimat "aku suka banget produk cleanser ini." [12]:

Unigram: 'aku', 'suka', 'banget', 'produk', 'cleanser', 'ini'.

Bigram: 'aku suka', 'suka banget', 'banget produk', 'produk cleanser', 'cleanser ini'.

\section{Metode Penelitian}

Dalam penelitian ini, dilakukan pengolahan data terhadap data tweet pengguna twitter yang diambil dari Twitter API. Data tersebut kemudian masuk ke tahap preprocessing untuk menghindari data yang kurang sempurna, gangguan pada data, dan data-data yang tidak konsisten sehingga keluaran dari klasifikasi memiliki keakurasian yang tinggi. Tahapan dalam preprocessing yaitu :

1. Case folding

Case folding dengan mengubah semua huruf menjadi huruf kecil.

2. Cleaning

Cleaning adalah tahap dimana karakter selain huruf dihilangkan dan menghapus URL, Username dan Mention.

3. Tokenizing

Tokenizing adalah tahap pemotongan string input berdasarkan tiap kata yang menyusunnya. Hasil dari proses ini adalah berupa kumpulan kata-kata tanpa tandabaca, karakter, dan angka

4. Filtering

Proses filtering ini adalah untuk menghapus setiap kata-kata yang tidak memiliki arti atau kata-kata yang sering muncul pada data komentar. 


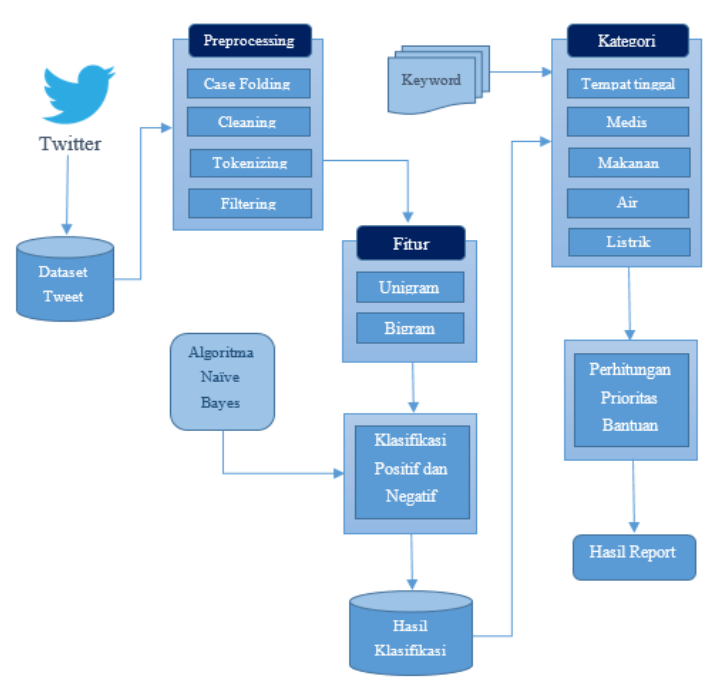

Gambar 1. Metode Pengolahan Data

Pada gambar 1 dijelaskan metode pengolahan data mulai dari proses crawling menggunakan Twitter API, setelah itu masuk ke tahap preprocessing, lalu data hasil preprocessing tersebut masuk tahap klasifikasi positif atau negatif dengan fitur unigram dan bigram menggunakan algoritma Nä̈ve Bayes kemudian disimpan ke dalam database lalu dikategorikan untuk menentukan objek yang telah di klasifikasi dengan menggunakan beberapa kategori dan keyword seperti berikut :

TABEL I. KATEGORI DAN KEYWORD

\begin{tabular}{|c|c|c|}
\hline No & Kategori & Keyword \\
\hline & $\begin{array}{l}\text { Tempat } \\
\text { tinggal }\end{array}$ & $\begin{array}{l}\text { Tempat tinggal, hunian, rumah, } \\
\text { pengungsian, bangun, } \\
\text { pemukiman }\end{array}$ \\
\hline 2 & Medis & $\begin{array}{l}\text { Medis, obat, sakit, penyakit, } \\
\text { kesehatan, dokter }\end{array}$ \\
\hline 3 & Makanan & $\begin{array}{l}\text { Makan, bahan pokok, lapar, } \\
\text { pangan }\end{array}$ \\
\hline 4 & Air & Air, minum, haus \\
\hline 5 & Listrik & Listrik, padam \\
\hline
\end{tabular}

Kategori dan keyword pada tabel 1 didapatkan dari hasil observasi dan jurnal sebelumnya yang melakukan penelitian mengenai bencana alam. Setelah dilakukan pengkategorian selanjutnya menghitung prioritas bantuan berdasarkan hasil testing dan kategori kemudian sistem akan menampilkan hasil report.

\section{Pengujian Sistem}

\subsection{Pengujian Akurasi Algoritma (Accuracy, Precision, Recall)}

Pada pengujian akurasi algoritma dilakukan pengujian terhadap hasil klasifikasi data testing. Dalam mengetahui keberhasilan algoritma dalam proses klasifikasi maka akan dibandingkan hasil klasifikasi yang dilakukan oleh sistem dengan hasil klasifikasi pelabelan manual hasil kuisioner sebanyak 15 orang responden. Perbandingan tersebut akan dihitung tingkat kebenaranannya menggunakan accuracy, precision dan recall. Semakin tinggi nilai accuracy, precision dan recall sebuah algoritma yang digunakan maka semakin menunjukkan bahwa algoritma tersebut bekerja dengan baik untuk proses klasifikasi.

Pengujian dilakukan dengan memilih data training dan data testing secara acak dari 300 data yang akan digunakan. Komposisi pembagian data training dan data testing dapat dilihat pada tabel 5.9.

TABEL II. PRESENTASE DATA

\begin{tabular}{|c|c|c|c|}
\hline \multicolumn{2}{|c|}{ Presentase Data } & \multicolumn{2}{c|}{ Jumlah Data } \\
\hline Training & Testing & Training & Testing \\
\hline $60 \%$ & $40 \%$ & 180 & 120 \\
\hline $70 \%$ & $30 \%$ & 210 & 90 \\
\hline $80 \%$ & $20 \%$ & 240 & 60 \\
\hline $90 \%$ & $10 \%$ & 270 & 30 \\
\hline
\end{tabular}

Pengujian selanjutnya dilakukan dengan memilih secara acak data training dan testing dari 300 data tersebut. Data training dipilih sebaanyak $60 \%$ dan $40 \%$ digunakan untuk data testing.

TABel III. Pengujian Data Training 60\% DAN DATA TESTING $40 \%$

\begin{tabular}{|c|l|l|l|l|l|}
\hline \multicolumn{5}{|c|}{ Data Training 60\% : Data Testing 40\% } \\
\hline Ketera & \multicolumn{5}{|c|}{ Pengujian } \\
\cline { 2 - 6 } ngan & $\begin{array}{c}\text { Accur } \\
\text { acy }\end{array}$ & $\begin{array}{c}\text { Precisi } \\
\text { on+ }\end{array}$ & $\begin{array}{c}\text { Precis } \\
\text { ion- }\end{array}$ & $\begin{array}{c}\text { Reca } \\
l l+\end{array}$ & $\begin{array}{c}\text { Reca } \\
l l-\end{array}$ \\
\hline Unigra & 76.67 & 78.65 & 70.97 & 88.6 & 53.6 \\
$m$ & $\%$ & $\%$ & $\%$ & $1 \%$ & $6 \%$ \\
\hline Bigram & 64.17 & 82.19 & 62.96 & 75.9 & 41.4 \\
& $\%$ & $\%$ & $\%$ & $5 \%$ & $6 \%$ \\
\hline
\end{tabular}

Melalui pengujian pada tabel 5.10 didapatkan bahwa nilai accuracy dari unigram sebesar $76.67 \%$ dan bigram sebesar $64.17 \%$. Nilai precision positif memiliki nilai $78.65 \%$ untuk unigram dan $82.19 \%$ untuk bigram. Precision negatif memiliki nilai $70.97 \%$ untuk unigram dan $62.96 \%$ untuk bigram. Recall positif memiliki nilai $88.61 \%$ untuk unigram dan $75.95 \%$ untuk bigram. Recall negatif memiliki nilai $53.66 \%$ untuk unigram dan $41.46 \%$ untuk bigram. Hal tersebut menunjukkan bahwa untuk pengujian dengan data training $60 \%$ dan testing $40 \%$ nilai accuracy, precision negatif, recall positif dan recall negatif pada unigram lebih baik daripada bigram. Sedangkan untuk precision positif bigram lebih baik daripada unigram. 
TABel iV. Pengujian Data TRAining 70\% Dan DATA TESTING 30\%

\begin{tabular}{|c|l|l|l|l|l|}
\hline \multicolumn{5}{|c|}{ Data Training 70\% : Data Testing 30\% } \\
\hline \multirow{2}{*}{$\begin{array}{c}\text { Ketera } \\
\text { ngan }\end{array}$} & \multicolumn{5}{|c|}{ Penguian } \\
\cline { 2 - 6 } & $\begin{array}{c}\text { Accur } \\
\text { acy }\end{array}$ & $\begin{array}{c}\text { Precisi } \\
\text { on+ }\end{array}$ & $\begin{array}{c}\text { Precis } \\
\text { ion- }\end{array}$ & $\begin{array}{c}\text { Reca } \\
\text { ll+ }\end{array}$ & $\begin{array}{c}\text { Reca } \\
\text { ll- }\end{array}$ \\
\hline Unigra & 84.44 & 86.36 & 79.17 & 91.9 & 67.8 \\
$m$ & $\%$ & $\%$ & $\%$ & $4 \%$ & $6 \%$ \\
\hline Bigram & 68.89 & 80.95 & 78.57 & 82.2 & 39.2 \\
& $\%$ & $\%$ & $\%$ & $6 \%$ & $9 \%$ \\
\hline
\end{tabular}

Dilakukan pengujian kedua pada tabel 5.11 dengan perbandingan data training sebesar $70 \%$ dan data testing sebesar $30 \%$. Nilai accuracy, precision positif, precision negatif, recall positif dan recall negatif didapatkan bahwa keseluruhan nilai untuk unigram cenderung lebih tinggi daripada bigram.

Tabel V. Pengujian Data Training $80 \%$ Dan DATA TESTING 20\%

\begin{tabular}{|c|l|l|l|l|l|}
\hline \multicolumn{5}{|c|}{ Data Training 80\%: Data Testing 20\% } \\
\hline Ketera & \multicolumn{5}{|c|}{ Penguian } \\
\cline { 2 - 6 } ngan & $\begin{array}{c}\text { Accur } \\
\text { acy }\end{array}$ & $\begin{array}{c}\text { Precisi } \\
\text { on+ }\end{array}$ & $\begin{array}{c}\text { Precis } \\
\text { ion- }\end{array}$ & $\begin{array}{c}\text { Reca } \\
l l+\end{array}$ & $\begin{array}{c}\text { Reca } \\
l l-\end{array}$ \\
\hline Unigra & 90.00 & 93.02 & 82.35 & 93.0 & 82.3 \\
$m$ & $\%$ & $\%$ & $\%$ & $2 \%$ & $5 \%$ \\
\hline Bigram & 75.00 & 80.43 & 100.00 & 86.0 & 47.0 \\
& $\%$ & $\%$ & $\%$ & $5 \%$ & $6 \%$ \\
\hline
\end{tabular}

Pengujian ketiga pada tabel 5.12 dilakukan dengan menggunakan perbandingan data training sebesar $80 \%$ dan $20 \%$. Nilai accuracy, precision positif, precision negatif, recall positif dan recall negatif mengalami peningkatan dari sebelumnya dan didapatkan bahwa unigram nilainya lebih tinggi daripada bigram.

\section{Tabel Vi. Pengujian Data Training 90\% DAN DATA TESTING 10\%}

\begin{tabular}{|c|l|l|l|l|l|}
\hline \multicolumn{5}{|c|}{ Data Training 90\% : Data Testing 10\% } \\
\hline \multirow{2}{*}{$\begin{array}{c}\text { Ketera } \\
\text { ngan }\end{array}$} & $\begin{array}{c}\text { Accur } \\
\text { acy }\end{array}$ & $\begin{array}{c}\text { Precisi } \\
\text { on+ }\end{array}$ & $\begin{array}{c}\text { Precis } \\
\text { ion- }\end{array}$ & $\begin{array}{c}\text { Reca } \\
l l+\end{array}$ & $\begin{array}{c}\text { Reca } \\
l l-\end{array}$ \\
\hline Unigra & 93.33 & 95.65 & 85.71 & 95.6 & 85.7 \\
$m$ & $\%$ & $\%$ & $\%$ & $5 \%$ & $1 \%$ \\
\hline Bigram & 86.67 & 91.30 & 100.00 & 91.3 & 71.4 \\
& $\%$ & $\%$ & $\%$ & $0 \%$ & $3 \%$ \\
\hline
\end{tabular}

Pengujian keempat pada tabel 5.13 dilakukan dengan menggunakan perbandingan data training sebesar $90 \%$ dan $10 \%$. Nilai accuracy, precision positif, precision negatif, recall positif dan recall negatif juga meningkat dari pengujian sebelumnya dan unigram tetap mendapatkan nilai lebih tinggi daripada bigram meskipun sama-sama mengalami peningkatan.
Dari hasil keempat pengujian diatas, nilai accuracy algoritma Nä̈ve Bayes Classifier untuk unigram secara berturut-urut didapatkan sebesar $76.67 \%, 84.44 \%, 90.00 \%$ dan $93.33 \%$. Nilai akurasi terendah adalah $76.67 \%$ dan tertinggi adalah 93.33\%. Nilai accuracy untuk bigram secara berturut-urut didapatkan hasil sebesar $64.17 \%, 68.89$ $\%, 75.00 \%, 86.67 \%$. Nilai akurasi terendah adalah $64.17 \%$ dan tertinggi adalah $86.67 \%$.

Dapat disimpulkan bahwa penggunaan fitur unigram ternyata akurasinya lebih tinggi daripada bigram, hal tersebut dikarenakan kata tunggal dalam bentuk unigram ternyata lebih banyak dipakai pada suatu kalimat dan umum penggunaanya, untuk bigram terdapat kata-kata khusus yang memang jarang digunakan pada suatu kalimat atau tweet. Contohnya terdapat tweet "ratusan pengungsi kalianda butuh makan minum" apabila dilakukan perhitungan tf maka kata "butuh" lebih banyak digunakan daripada kata "butuh makan". Oleh karenanya hasil akurasi unigram lebih tinggi daripada bigram.

Selanjutnya, setiap terjadi penambahan data training, maka nilai dari accuracy, precision dan recall juga mengalami peningkatan. Hal ini dikarenakan algoritma nä̈ve bayes merupakan metode supervised learning yang sangat bergantung pada data training, kemungkinan akurasi dapat ditingkatkan lagi dengan menambahkan data training yang banyak. Seperti hasil dari penelitian ini pada gambar 5.33 dan 5.34 setiap terjadi penambahan data training maka akurasinya cenderung mengalami peningkatan.

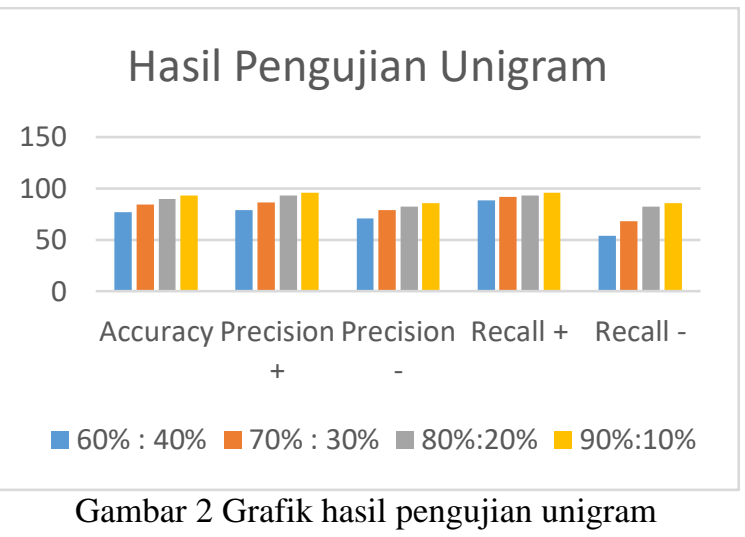

Gambar 2 Grafik hasil pengujian unigram 


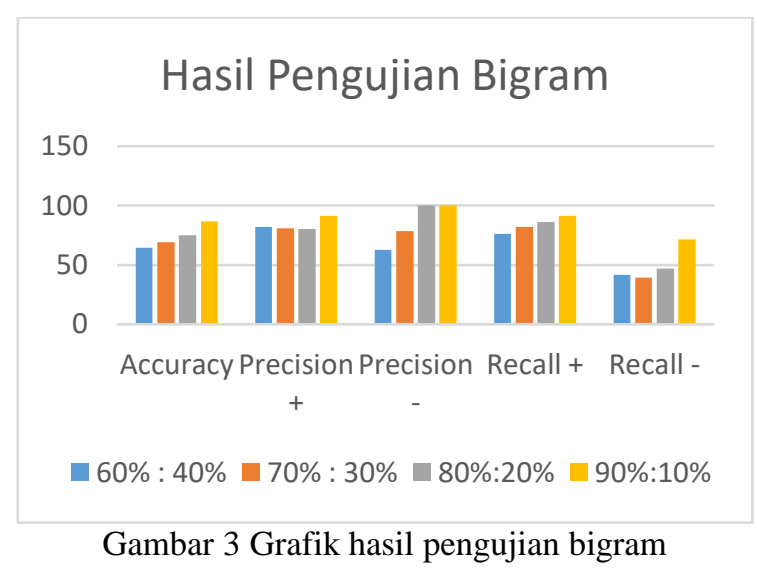

\subsection{Pengujian Akurasi Kategori}

Pengujian akurasi kategori bertujuan untuk menguji akurasi keberhasilan suatu tweet masuk kedalam kategori yang sesuai berdasarkan keyword yang telah ditentukan sebelumnya. Pengujian dilakukan dengan menggunakan sampel $10 \%$ dari dataset yaitu sebanyak 30 tweet yang telah terklasifikasi.

Dari 5 kategori tersebut semuanya memiliki akurasi yang tinggi sebesar $100 \%$ hal tersebut dikarenakan keyword yang digunakan semuanya dapat terdeteksi pada suatu tweet dan dapat terkategori sesuai dengan yang diinginkan seperti yang terlihat pada gambar 4 .

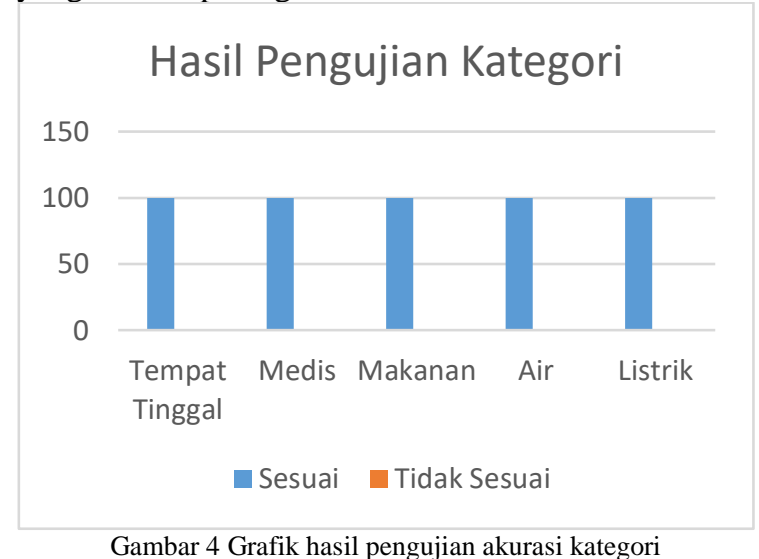

Selanjutnya untuk hasil perhitungan prioritas bantuan dari hasil klasifikasi dapat dilihat pada tabel 5.19 .

TABEL VII. PERHITUNGAN PRIORITAS BANTUAN

\begin{tabular}{|l|l|l|l|}
\hline No & \multicolumn{1}{|c|}{ Kategori } & \multicolumn{1}{|c|}{ Positif } & Negatif \\
\hline 1 & Tempat Tinggal & 0.1 & 0.1 \\
\hline 2 & Medis & 0.2 & 0.333333 \\
\hline 3 & Makanan & 0.233333 & 0.333333 \\
\hline 4 & Air & 0.333333 & 0.333333 \\
\hline 5 & Listrik & 0.2 & 0.333333 \\
\hline
\end{tabular}

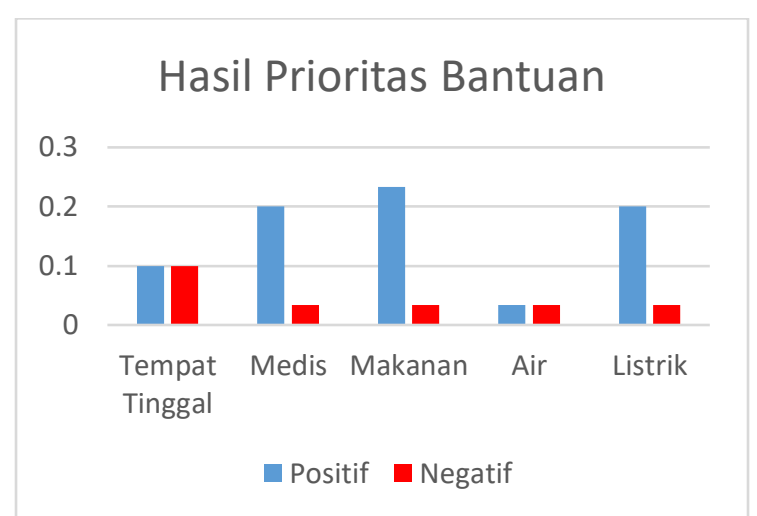

Gambar 5. Grafik hasil perhitungan prioritas

Pada hasil perhitungan prioritas bantuan terdapat diagram positif dan negatif pada setiap kategori. Positif diartikan bantuan berdasarkan kategori tersebut telah terpenuhi sedangkan negatif berarti bantuan tersebut kurang atau dibutuhkan. Berdasarkan gambar 5.35 dapat diketahui jika bantuan makanan sudah sangat terpenuhi dan untuk bantuan tempat tinggal posisinya sejajar antara terpenuhi dan kurang, akan tetapi dari kelima kategori tersebut ketegori yang paling dibutuhkan adalah tempat tinggal.

\section{Kesimpulan Dan Saran}

\subsection{Kesimpulan}

Berdasarkan hasil penelitian dan pengujian yang telah dilakukan dapat ditarik kesimpulan sebagai berikut:

1. Algoritma Nä̈ve Bayes Classifier dapat digunakan untuk mengklasifikasikan tweet kedalam positif atau negatif terutama tweet mengenai pasca bencana.

2. Pengujian akurasi algoritma yang dilakukan dengan pemberian label manual dari 15 responden, didapatkan hasil dari unigram dan bigram memiliki perbedaan yang cukup signifikan. Dari empat pengujian tersebut didapatkan hasil akurasi tertinggi pada unigram yaitu sebesar $93.33 \%$ dan bigram sebesar $86.67 \%$. Nilai akurasi unigram cenderung lebih tinggi daripada bigram, hal tersebut dikarenakan kata tunggal dalam bentuk unigram ternyata lebih banyak dipakai pada suatu kalimat dan umum penggunaanya, untuk bigram terdapat kata-kata khusus yang memang jarang digunakan pada suatu kalimat atau tweet. Jumlah data training yang digunakan juga berpengaruh dengan peningkatan akurasi terhadap hasil klasifikasi menggunakan algoritma Nä̈ve Bayes Classifier.

3. Pada pengujian akurasi kategori didapatkan hasil akurasi yang tinggi yaitu sebesar $100 \%$ hal tersebut dikarenakan keyword yang digunakan semuanya dapat terdeteksi pada 
suatu tweet dan dapat terkategori sesuai dengan yang diinginkan.

\subsection{Saran}

Saran yang dapat diberikan dari hasil penelitian untuk pengembangan sistem ini kedepan sebagai berikut :

1. Sistem dapat melakukan crawling data secara real time menggunakan Twitter API.

2. Dapat dikembangkan dengan penambahan fitur yang lain seperti POS-Tagging.

\section{Daftar Pustaka}

Alejandro Quiroz Flores. 2018. "Bencana Alam Bisa Runtuhkan Demokrasi Indonesia".

https://www.matamatapolitik.com/bencana-alam-bisaruntuhkan-demokrasi-indonesia/.

Ting, S. L., Ip, W. H., \& Tsang, A. H. 2011. "Is Naïve Bayes a Good Classifier for Document Classification?" International Journal of Software Engineering and Its Applications, 5(3), 3746.

Yusra, Dhita Olivita, Yelfi Vitriani. "Perbandingan Klasifikasi Tugas Akhir Mahasiswa Jurusan Teknik Informatika Menggunakan Metode Naïve Bayes Classifier dan KNearest Neighbor". Jurnal Sains, Teknologi dan Industri, Vol. 14, No. 1, Desember 2016, pp. 79 - 85

Wahyu Candra Indhiarta. 2017. "Penggunaan N-Gram Pada Analisa Sentimen Pemilihan Kepala Daerah Jakarta Menggunakan Algoritma Naïve Bayes". Fakultas Komunikasi Dan Informatika Universitas Muhammadiyah Surakarta.

Denny Nathaniel Chandra, Gede Indrawan, I Nyoman Sukajaya "Klasifikasi Berita Lokal Radar Malang Menggunakan Metode Naïve Bayes Dengan Fitur N-Gram". Jurnal
Ilmiah Teknologi dan Informasia ASIA (JITIKA) Vol.10, No.1, Februari 2016

[6] Tetsuya Nasukawa, Jeonghee Yi. 2003. "Sentimen Analysis Capturing favorability using Natural Language Processing".

[7] Irena Pletikosa Cvijikj, Florian Michahelles . 2011. "Understanding Social Media Marketing: A Case Study on Topics, Categories and Sentiment on a Facebook Brand Page".

[8] Luiz F. S. Coletta, N'adia F. F. da Silva, Eduardo R. Hruschka, Estevam R. Hruschka Jr. 2014. "Combining Classification and Clustering for Tweet Sentiment Analysis".

[9] Nurrun Muchammad Shiddieqy Hadna, Paulus Insap Santosa, Wing Wahyu Winarno . "Studi Literatur Tentang Perbandingan Metode Untuk Proses Analisis Sentimen di Twitter". Seminar Nasional Teknologi Informasi dan Komunikasi 2016 (SENTIKA 2016)

[10] Amir Hamza. 2012 "Klasifikasi Teks Dengan Naïve Bayes Classifier (NBC) Untuk Pengelompokan Teks Berita Dan Abstract Akademis" Prosiding Seminar Nasional Aplikasi Sains \& Teknologi (SNAST) Periode III

[11] Le Quan Ha , E. I. Sicilia-Garcia, Ji Ming and F. J. Smith. 2003. "Extension of Zipf's Law to Word and Character N-grams for English and Chinese". Journal of Computational Linguistics and Chinese Language Processing.

[12] Annisya Aprilia Prasanti, M. Ali Fauzi, M. Tanzil Furqon. 2018. "Klasifikasi Teks Pengaduan Pada Sambat Online Menggunakan Metode NGram dan Neighbor Weighted K-Nearest Neighbor (NW-KNN)". Jurnal Pengembangan Teknologi Informasi dan Ilmu Komputer. 